\title{
Gambaran School Well-Being pada Peserta Didik Program Kelas Akselerasi di SMA Negeri 8 Yogyakarta
}

\author{
Husnul Khatimah \\ Program Studi Tarbiyah Universitas Muhammadiyah Palu \\ Jl. Hang Tuah No. 114, Talise, Palu, Sulawesi Tengah, Indonesia \\ Email: chenoel86@gmail.com
}

\begin{abstract}
This research is about the school well-being for acceleration class's students in SMA Negeri 8 Yogyakarta. The Researcher wanted to describe the school well-being and its main factors which contributed to acceleration students' school well-being in SMA Negeri 8 Yogyakarta. The data was collected by interview, observation, and documentation study. The research subject was taken with purposive sampling a number of 39 students. The analysis of data using data triangulation technique. The research showed that the school well-being of acceleration students in SMA Negeri 8 Yogyakarta were described as well perceived on school infrastructure, excellent individual capital, unwell learning design management, well interpersonal school interaction, well school management, and perceived parental support. The result of this research can be used as the school's fundamental consideration in creating learning atmosphere which led to well-being school condition.
\end{abstract}

Keywords: school well-being, acceleration, learning atmosphere, triangulation technique

\begin{abstract}
Penelitian ini merupakan penelitian tentang gambaran school well-being pada peserta didik kelas akselerasi di SMA Negeri 8 Yogyakarta. Penelitian bertujuan untuk mendeskripsikan school well-being dan untuk mengetahui faktor-faktor yang berkontribusi terhadap school well-being siswa kelas akselerasi. Data yang dihimpun oleh peneliti, ditempuh melalui tiga cara yaitu, wawancara, observasi dan studi dokumen. Subjek penelitian diambil dengan purposive sampling sejumlah 39 siswa. Analsis data menggunakan teknik trianggulasi data. Hasil penelitian menunjukkan gambaran school well-being siswa akselerasi di SMA Negeri 8 Yogyakarta adalah well perceived on school infrastructure, excellent individual capital, unwell learning design management, well interpersonal school interaction, well school management, dan perceived parental support. Hasil penelitian ini dapat dijadikan dasar pertimbangan sekolah dalam menciptakan iklim belajar yang mengarah pada kondisi sekolah yang well being.
\end{abstract}

Kata kunci : school well-being, akselerasi, iklim belajar, teknik triangulasi

\section{Pendahuluan}

Pengalaman sekolah yang kurang menyenangkan dapat menjadi sumber stres yang signifikan dan mengurangi kualitas hidup bagi peserta didik (Huebner \& McCullough, 2000). Pernyataan Huebner dan McCullough didukung dengan penelitian Fatimah (2010), yang menunjukkan bahwa semakin tinggi stres yang dialami siswa, maka akan diikuti dengan semakin buruknya penilaian siswa terhadap sekolahnya. Ketika siswa mengalami kejenuhan, maka ia akan merasa tidak memiliki hubungan sosial yang baik dan pemenuhan dirinya di sekolah terasa seperti diabaikan. Pendapat tersebut sesuai dengan penelitian yang dilakukan oleh Torsheim (Fatimah, 2010) bahwa stres yang dialami oleh siswa akan memberikan dampak yang buruk pada hubungan interpersonal, kemudian keadaan stres tersebut dapat membuatnya merasa bahwa iklim belajar di sekolahnya tidak menyenangkan.

Kondisi sekolah yang tidak menyenangkan, menekan, dan membosankan akan berakibat pada pola siswa yang bereaksi negatif, seperti stres, bosan, terasingkan, kesepian dan depresi. Kondisi tersebut akan berdampak pada penilaian individu terhadap sekolahnya. Pengukuran penilaian subjektif siswa terhadap terpenuhinya kebutuhan di 


\section{KHATIMAH}

sekolah disebut sebagai school wellbeing yang dikembangkan oleh Konu dan Rimpela (2002).

Well-being pada siswa dapat dilihat dari penilaian mereka terhadap keadaan sekolah mereka sendiri, bagaimana peran sekolah dalam proses belajar mereka khususnya para siswa program akselerasi. Sesuai dengan Tian, (2008) sekolah merupakan konteks lingkungan sosial yang kuat dan potensial sebagai sarana atau tempat perkembangan sosial remaja. Terlebih lagi sekolah merupakan sarana yang potensial dalam membentuk kepribadian individu serta konsep sosial yang baik yang akhirnya akan memberikan kesejahteraan itu sendiri terhadap siswa,

Program school well-being menjadi penting diterapkan di sekolah, karena siswa yang sehat, merasa bahagia dan sejahtera dalam mengikuti pelajaran di kelas, dapat belajar secara efektif dan memberi kontribusi positif pada sekolah dan lebih luas lagi pada komunitas (Konu \& Rimpela, 2006). Pendapat selanjutnya dikemukakan Morris (2009) bahwa well-being harus menjadi fungsi pendidikan utama, dan semua sekolah harus digerakkan untuk memaksimalkan pertumbuhan siswa dan pendidik.

Keinginan pemerintah indonesia untuk memberikan pelayanan terbaik bagi warga, termanifestasi melalui program pendidikan. Pemerintah berupaya menaikkan kualitas mutu pendidikan melalui banyak program, dan satu di antaranya adalah layanan pendidikan bagi anakanak dengan intelegensi diatas rata-rata normal atau yang disebut dengan anak berbakat.

Pada tahun 1998 Munandar melakukan survei di beberapa Provinsi tentang kebijakan pendidikan keterbakatan di Indonesia dengan responden para pakar, kepala sekolah, guru siswa berbakat, guru siswa biasa, orang tua siswa berbakat dan orang tua siswa biasa, ternyata seluruh responden menyetujui dilakukan akselerasi atau percepatan secara fleksibel dalam pendidikan keterbakatan (Munandar, 1999). Sampai saat ini tampaknya program akselerasi masih dalam tahap uji coba dan belum semua sekolah dapat menyelenggarakan program akselerasi. Yogyakarta khususnya, sekolah yang telah menyelenggarakan program akselerasi ini salah satunya adalah SMAN 8 Yogyakarta.

Program akselerasi sangat berbeda dengan program pendidikan lainnya. Program terakhir diperbaharui pada RAKERNAS tahun 2000 ini, mencanangkan percepatan belajar atau akselerasi sejak pada tingkat sekolah dasar (SD), sekolah menengah pertama (SMP), hingga sekolah menengah atas (SMA). Program ini bertujuan untuk menghargai peserta didik yang memiliki kemampuan dan kecerdasan luar biasa untuk dapat menyelesaikan pendidikan lebih cepat. Tujuan lain yaitu memacu kualitas peserta didik dalam meningkatkan spiritual, intelektual dan emosional secara berimbang, serta meningkatkan efektifitas dan efisieni proses pembelajaran peserta didik (Nisichin, dalam Hawadi, 2004)

Kelas akselerasi yang diperpendek dari tiga tahun menjadi dua tahun membuat aktivitas belajar siswa kelas akselerasi menjadi padat, jumlah jam belajar di sekolah lebih banyak dibandingkan dengan jumlah jam belajar siswa kelas reguler. Selain itu setiap hari siswa kelas akselerasi diberi tugas atau pekerjaan rumah, khususnya mata pelajaran non-esensial. Aktivitas dan tugas belajar yang padat membuat siswa menggunakan banyak waktunya untuk belajar, melakukan kegiatan belajar bersama, menggunakan banyak sumber belajar, dan menggunakan berbagai strategi belajar, baik strategi kognitif maupun strategi mengelola lingkungan dan sumber daya. Aktivitas belajar yang padat menjadikan siswa kelas akselerasi mampu melakukan regulasi diri dalam belajar (Alsa, 2004). Pemperkayaan materi juga diperoleh siswa kelas akselerasi melalui tugas mandiri dan tugas kelompok yang dikerjakan di luar jam sekolah.

Beban dan tugas belajar di dalam dan di luar jam sekolah ternyata menjadi stressor positif (eustress) bagi siswa kelas akselerasi. Hal ini dapat terjadi karena perkembangan fisik siswa sudah kuat, perkembangan kognitif siswa sudah siap, dan yang lebih penting adalah bahwa siswa cerdas dan berbakat, learning ratenya lebih unggul dibandingkan siswa normal seusianya. Mereka mampu mengubah sikap mental dalam menghadapi kecepatan dan kepadatan belajar, sehingga mereka lebih aktif, memiliki komitmen, dan fight dalam belajar (Alsa, 2004)

Program akselerasi menunjukkan bahwa pada awalnya sebagian besar guru dan administrator berpendapat bahwa akselerasi itu bisa baik dan buruk bagi anak-anak, terutama secara emosi dan sosial. Hasil dari penelitian bahwa akselerasi itu baik bagi anak-anak dan tidak berbahaya. Ketika anak-anak diberikan program akselerasi, mereka jarang mengalami tekanan secara emosi dan tertutup dari lingkungan sosialnya yang menakutkan. Hal ini tidak sulit untuk dimengerti ketika orang menyadari bahwa akselerasi telah diterapkan untuk mengatasi masalah seperti: anak bosan di sekolah, guru menyadari bahwa ia tidak bisa menyediakan kebutuhan anak di ruang kelas, 
anak tidak merespon ketika ditanya sesuatu yang dipelajari beberapa tahun yang lalu. Dengan demikian, akselerasi hampir tidak pernah mengganggu masa kanak-kanak mereka. Perbaikan kurikulum untuk anak dapat meringankan situasi belajarnya daripada menciptakan situasi stres. Pernyataan dari riset yang menyatakan bahwa tidak diragukan karena akselerasi itu dapat dilihat sebagai metode yang bagus tanpa konsekuensi negatif (Rogers, 2002).

Sejalan dengan yang diutarakan oleh Davis (2012) bahwa dalam beberapa penelitian terdahulu, motivasi peserta didik yang kelasnya dipercepat semakin meningkat. Mereka tidak menjadi pemalas, seperti yang terjadi pada anak yang tidak akseleran. Ilmu pengetahuan mereka meningkat, karena sekolah mengakui dan mengakomodasikan kemampuan mereka. Mereka berusaha belajar karena mereka dihadapkan dengan materi yang belum mereka ketahui.

Riset lain menemukan persoalan yang justru sebaliknya yakni, Hawadi (2004) memaparkan bahwa remaja yang mengikuti program akselerasi merasa frustasi dengan adanya tekanan dan tuntutan yang ada, dan bisa mengakibatkan siswa menjadi siswa yang underachiver. Sekitar 20-25 persen dari remaja yang mengikuti program akselerasi ini mengalami masalah sosial dan emosional. Permasalah tersebut didukung pula oleh hasil penelitian Maimunah (2009) yang menyatakan bahwa siswa akselerasi merasa kurang puas terhadap waktu istrahat dan bermainnya dikarenakan terlalu banyak tugas yang harus dikerjakan, dan juga merasa tertekan karena dianggap mampu dalam segala hal oleh gurunya, padahal siswa akseleran tersebut masih butuh pengarahan dan penjelasan. Pengalaman yang tidak menyenangkan tersebut memiliki dampak pada perkembangan emosi dan sosial peserta akslerasi.

Masalah lain yang menyangkut akselerasi adalah masalah jumlah siswa dikelas, sistem evaluasi, kompetensi guru, dan cara pembelajaran. Jumlah siswa yang terlalu banyak dikelas menyebabkan guru kurang mengenal potensi setiap anak. Apalagi jika guru tidak menerapkan Individual Educational Program (IEP) karena jumlah siswa yang melebihi kapasitas yang ideal (40-50 siswa perkelas). Selain itu sudah menjadi rahasis umum bahwa banyak guru yang kurang menguasai materi serta pengayaan materi sehingga tidak mampu menampung aspirasi siswa. Lagi pula selama sistem evaluasi yang digunakan adalah pilihan ganda yang kurang menggali kemampuan potensial siswa secara optimal, guru kurang dapat gambaran yang tepat mengenai kemampuan siswa. Sensitivitas guru dalam menemukan keberbakatan anak menjadi terabaikan. Jarangnya digunakan evaluasi portofoliojuga menyebabkan hilangnya sentuhan pribadi guru pada siswa (Hawadi, 2004).

Kolesnik (1970) mengemukakan adanya kelemahan program akselerasi, adalah dengan loncat kelas akan mengurangi kesempatan siswa untuk bersosialisasi dengan teman sebayanya, menimbulkan problem sosial dan emosional, beban tugas belajar yang banyak bisa menjadi tekanan (stressor) bagi kesehatan mental, kesempatan untuk latihan kepemimpinan berkurang karena masalah fisik dan kematangan sosialnya belum sematang siswa lainnya yang lebih tua, melakukan akselerasi dalam perkembangan intelektual, tapi tidak dalam aspek-aspek lainnya, belajar tidak sekedar menguasai ilmu pengetahuan, tapi berfikir, mencari dan menggali pengetahuan, mengerti, menilai, dan membandingkan.

Fakta lapangan yang memperkuat asumsi permasalahan pada kelas akselerasi ditemukan pada saat studi pendahuluan. Berdasarkan data temuan sebagaimana Gambar 1, diperoleh bahwa school well-being pada kelas 10 kelas akselerasi terdapat $40 \%$ peserta akselerasi merasa tidak puas dengan metode mengajar guru yang sulit dipahami. Siswa mengeluhkan bahwa guru yang terlalu cepat mengajar dan terkadang meremehkan pemahaman peserta didik sendiri, sehingga mereka kurang memahami materi. Sementara $25 \%$ masih dalam aspek having mengatakan masalah yang siswa hadapi selama menjadi peserta akselerasi adalah kurang fokus dalam mengikuti belajar. Kurang fokusnya mengikuti belajar dikarenakan terlalu banyak kegiatan sekolah maupun diluar sekolah.

Permasalahan lain yang dimiliki siswa akselerasi tentang banyaknya tumpukkan materi dan tugas yang harus dikerjakan dalam satu waktu yang singkat sejumlah 25\%. Permasalahan ini membuat siswa menjadi lelah dan sering mengantuk ketika di dalam kelas dan akhirnya membuat siswa tidak fokus dalam belajar. Dilihat dari aspek being atau pemenuhan diri terdapat $10 \%$ peserta didik mengakui bahwa belum mampu menyesuaikan diri dengan proses belajar di kelas akselerasi, sehingga siswa kurang mampu memanajemen waktu. Artinya siswa masih membutuhkan penyesuaian diri dengan gaya belajar program akselerasi. 


\section{KHATIMAH}

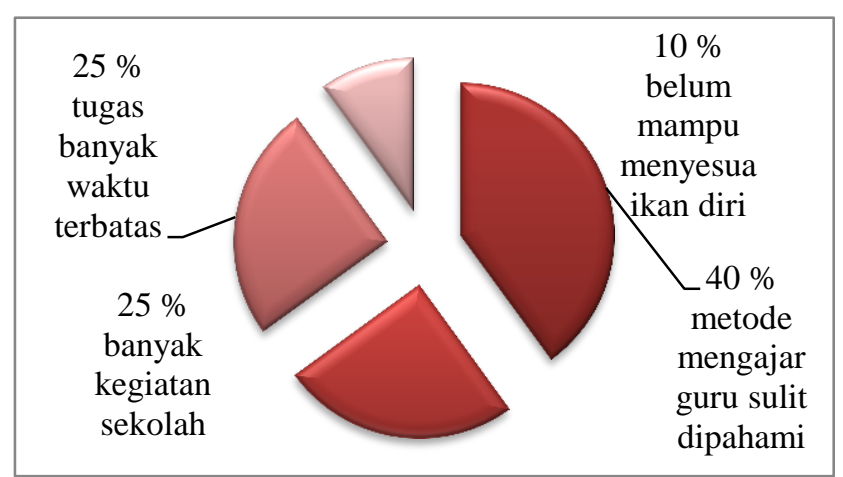

Gambar 1. Masalah Peserta Akselerasi kelas 10

Masih dalam data yang sama yakni hasil temuan pada penelitian pendahuluan pada kelas 12 akselerasi di SMA Negeri 8 Yogyakarta dilihat dari aspek having sebagaimana Gambar 2. bahwa $47.62 \%$ mengatakan masalah yang mereka hadapi selama menjadi peserta akselerasi adalah tumpukan tugas dan kegiatan luar sekolah yang banyak. Sementara $23.81 \%$ mengatakan masalah yang mereka hadapi adalah waktu belajar yang padat dengan berbagai materi. Disamping itu terdapat $23.81 \%$ peserta didik mengakui bahwa masalah lain yang mereka hadapi adalah metode guru yang terlalu cepat dalam mengajar, sehingga mereka tidak paham akan materi dan tertinggal dalam mengelolah informasi, Dan $4.76 \%$ peserta didik mengeluh akan beragam kegiatan ekstra yang dilakukan diluar proses belajar.

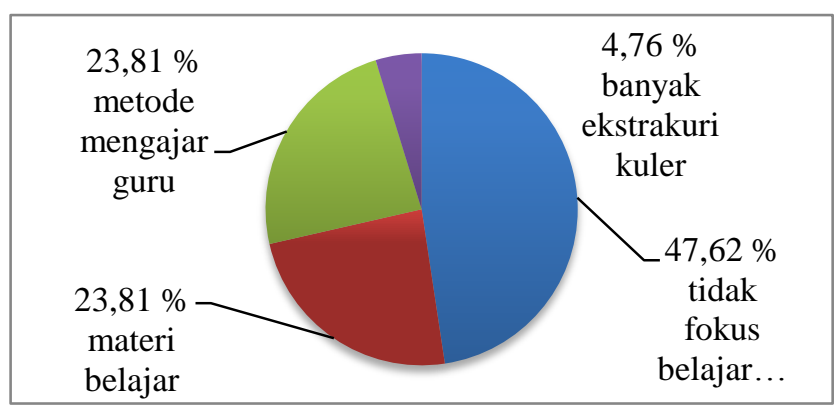

Gambar 2. Masalah Peserta Akselerasi kelas XII

Dari hasil temuan yang telah dipaparkan sebelumnya, terlihat bahwa masalah yang dihadapi oleh siswa akselerasi lebih berfokus pada aspek having dalam school well-beingyaitu pada metode mengajar guru yang kurang tepat dan tumpukan materi serta tugas sekolah yang sangat banyak dengan waktu yang singkat. Data diatas diperkuat oleh hasil wawancara yang dilakukan oleh peneliti kepada guru pembimbing khusus program akselerasi yang diketahui bahwa sejak awal didirikannya program akselerasi, banyak peserta didik yang mengeluh mengenai masalah tersebut. Meskipun demikian, tidak ada satupun peserta didik yang mengalami penurunan kelas atau pindak ke kelas reguler setelah lama menjadi akseleran. Kecenderungan yang muncul adalah motivasi peserta didik jauh lebih terpacu dalam belajar. Mereka memiliki strategi dalam menanggulangi masalah tersebut. Hal tersebut belaku pula dengan peserta kelas 10 dan 12. Utamanya pada kelas 10 , awal mula menjadi akseleran sering mengalami kendala dan masalah dalam belajar karena faktor metode mengajar guru yang kurang bisa dipahami oleh siswa dan waktu belajar yang sangat padat. Namun, masih ada beberapa siswa yang masih mengeluhkan masalah tersebut. (catatan lapangan penelitian pendahuluan pada bulan Februari, 2014).

Mendalami teori yang telah dikemukakan dan dikaitkan dengan fakta-fakta lapangan di atas, dapat dicermati lebih jauh bahwa pada prinsipnya peserta didik program akselerasi memiliki masalah dalam managemen sekolahnya dan managemen pembelajaran. Meskipun demikian, para akselaran tidak lantas menjadikan masalah tersebut sebagai sebuah hambatan besar selama menuntut ilmu disekolahnya. Berangkat dari asumsi tersebut yang kemudian mendorong peneliti untuk merumuskan masalah yaitu " Bagaimana Gambaran School Well-Being Peserta Didik kelas Akselerasi”,

Peneliti ini bertujuan untuk mendeskripsikan SchoolWell-Being dan untuk mengetahui faktorfaktor yang berkontribusi terhadap School WellBeing siswa kelas akselerasi di SMA Negeri 8 Yogyakarta. Kondisi sekolah yang tidak menyenangkan, menekan, dan membosankan akan berakibat pada pola siswa yang bereaksi negatif, seperti stres, bosan, terasingkan, kesepian dan depresi. Maka, gambaran faktor-faktor yang berkontribusi terhadap School Well-Being siswa kelas akselerasi penting untuk diketahui mengingat bahwa siswa akselerasi dituntut untuk dapat belajar secara cepat dan memiliki beban tugas belajar yang berbeda dengan siswa kelas reguler. Hasil penelitian dapat dijadikan dasar pertimbangan sekolah dalam menciptakan iklim belajar yang mengarah pada kondisi sekolah yang well being sehingga siswa dapat berkembang secara optimal terhindar dari kondisi depresi dan stres di lingkungan sekolah. 


\section{Kajian Literatur}

\section{School Well Being}

Lingkungan sekolah memiliki peranan penting dalam keberhasilan siswa belajar di sekolah. Salah satu faktor yang berpengaruh terhadap keberhasilan siswa belajar adalah school well bein . Diener 1984 (Tian, 2008) menerangkan bahwa well-being adalah konstruk multidimensional yang berdampak pada sikap positif seperti emosi yang positif dan selalu dalam keadaan suka cita. Well-being negatif maka akan mempengaruhi emosi yang negatif pula seperti mengalami kecemasan. Intinya adalah seseorang dengan well-being yang tinggi adalah individu yang memiliki pengalaman emosi yang positif, jarang terlibat dengan emosi negatif dan tingkat kepuasan hidup yang tinggi.

Beberapa faktor yang dapat mempengaruhi school well-being siswa menurut Keyes dan Waterman (Bornstein, Davidson, Keyes, \& Moore, 2003) yaitu hubungan sosial, teman dan waktu luang, volunteering, peran sosial, karakteristik kepribadian, kontrol diri dan sikap optimis, serta tujuan dan aspirasi. Pervin (Bornstein dkk, 2003) menyatakan bahwa individu yang memiliki rasa optimis mampu menyesuaikan diri dengan baik pada situasi tertentu seperti saat pergi ke sekoah.

Model school wellbeing yang dikembangkan oleh Konu dan Rimpela (2002) . School well-being merujuk kepada model konseptual well-being yang dikemukakan oleh Allardt (Konu dan Rimpela, 2002). Ia mendefinisikan well-being sebagai keadaan yang memungkinkan individu memuaskan kebutuhan-kebutuhan dasarnya yang mencakup kebutuhan material maupun non material. Kebutuhan tersebut dibagi oleh Allardt (Konu dan Rimpela, 2002) menjadi aspek having (kondisi sekolah), loving (hubungan sosial), being (pemenuhan diri), dan health (kesehatan).

Konsep tersebut memiliki harapan bahwa kesejahteraan sekolah siswa lebih penting, yaitu perasaan siswa dalam menilai kelayakan sekolah mereka sebagai lingkungan belajar yang mampu memberikan dukungan, rasa aman, dan nyaman. Selain itu, keadaan rumah siswa dan lingkungan sekitar juga berpengaruh terhadap sekolah siswa tersebut sehingga terbentuklah sebuah model school well-being sebagaimana Gambar 3. Berikut penjelasan masing masing aspek yang telah disebutkan.

\section{Having (Kondisi Sekolah)}

Meliputi lingkungan fisik di sekitar sekolah dan di dalam sekolah. Area yang diskusikan adalah lingkungan sekolah yang aman, kenyamanan, kebisingan, ventilasi, suhu udara, dan sebagainya. Aspek lain dari kondisi sekolah berhadapan dengan lingkungan belajar. Hal itu meliputi kurikulum, ukuran kelompok, jadwal dari pelajaran dan hukuman. Aspek ketiga meliputi pelayanan kepada siswa seperti makan siang di sekolah, pelayanan kesehatan, wali kelas dan guru bimbingan konseling (Konu \& Rimpela, 2002).

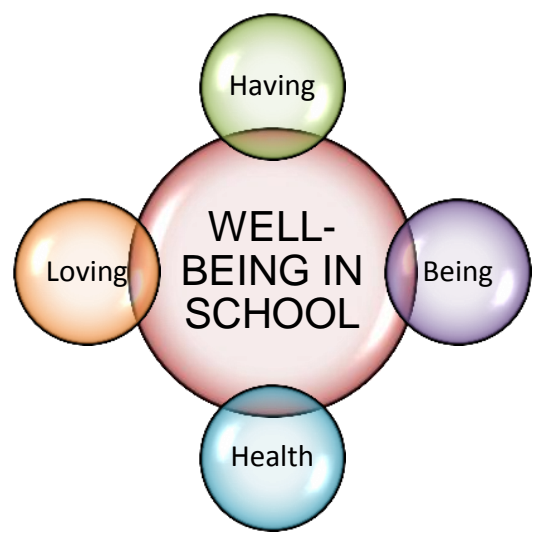

Gambar 3. Model School Well-Being

(Konu \& Rimpela, 2002)

\section{Loving (Hubungan Sosial)}

Merujuk kepada lingkungan sosial belajar, hubungan siswa guru, hubungan dengan teman sekelas, dinamika kelompok, kekerasan, kerja sama sekolah dengan rumah, pengambilan keputusan di sekolah dan suasana dari keseluruhan organisasi sekolah. Iklim sekolah dan iklim belajar mempunyai dampak pada kesejahteraan dan kepuasan siswa di dalam sekolah. Hubungan yang baik dan suasana yang baik merupakan untuk mempromosikan sumber manusia dalam masyarakat dan untuk meningkatkan prestasi di sekolah. Model sekolah sejahtera, hubungan di antara sekolah dengan rumah ditempatkan pada kategori hubungan sosial. Lebih lanjut, hubungan sekolah dengan lingkungan masyarakat adalah penting (misal hubungan dengan masalah sosial dan sistem pelayanan kesehatan). Hubungan siswa dengan guru merupakan peran penting dalam kesejahteraan di sekolah (Konu \& Rimpela, 2002).

\section{Being (Pemenuhan diri di Sekolah)}

Merujuk pada masing-masing individu menghargai sebagai bagian berharga dari masyarakat. Kesempatan untuk bekerja dengan penuh arti pada hidupnya dan untuk kesenangan secara alami juga bagian penting sekali dari pemenuhan diri. Dalam konteks sekolah, being dapat dilihat dengan bagaimana sekolah 


\section{KHATIMAH}

menawarkan untuk pemenuhan diri. Masing-masing siswa dapat mempertimbangkan sebagai anggota yang sama pentingnya dari komunitas sekolah. Seharusnya memungkinkan masing-masing siswa untuk berpartisipasi dalam pengambilan keputusan dari sekolahnya dan aspek lain dari sekolah yang berfokus pada dirinya. Kesempatan untuk meningkatkan pengetahuan dan ketrampilan siswa merupakan lahan yang menarik bagi siswa (Konu \& Rimpela, 2002).

\section{Health (Kesehatan)}

Health (status kesehatan) Status siswa ini meliputi aspek fisik dan mental berupa simtom psikosomatis, penyakit kronis, penyakit ringan (seperti flu), dan penghayatan akan keadaan diri (Konu \& Rimpela, 2002).

Well-being dapat dilihat dari dua indikator, yakni indikator objektif dan infikator subjektif. Indikator objektif didasarkan pada observasi eksternal dan indikator subjektif didasarkan pada ekspresi orang terhadap sikap mereka dan persepsi mereka terhadap kondisi lingkungannya (Konu \& Rimpela, 2002)

Pengertian akselerasi diberikan oleh Pressey 1949 (Colangelo, dkk, 2004) sebagai suatu kemajuan yang diperoleh dalam program pengajaran, pada waktu yang lebih cepat atau usia yang lebih muda dari pada yang konvensional. Hal ini sangat cocok diberikan pada siswa yang berbakat dan siswa yang muda yang memiliki kapasitas belajar yang tinggi. Program akselerasi ini memberikan tantangan yang tepat dan mengurangi waktu yang diperlukan siswa dalam menyelesaikan studinya.

Definisi ini menunjukkan bahwa akselerasi meliputi persyaratan untuk menghindari hambatan pemenuhan permintaan dalam pengajaran dan juga mengusulkan proses-proses yang memungkinkan siswa melalui pemberian materi yang lebih cepat dibanding dengan kemajuan rata-rata siswa (Hawadi, 2004).

\section{Metode Penelitian}

Penelitian dilakukan di SMA Negeri 8 Yogyakarta. Sampel yang digunakan dalam metode penelitian ini adalah sampling variasi maksimum yaitu mendokumentasikan beragam variasi dan mengidentifikasi pola-pola umum yang penting (Creswell 1998). Penelitian menggunakan pendekatan deskriptif kualitatif. Dalam penelitian ini peneliti membagi sample yang terdiri dari siswa akselerasi kedalam dua kelompok berdasarkan tingkatan kelas dan nilai akademik siswa. Kemudian dari masing-masing kelompok tersebut dipilih perwakilan untuk di wawancara. Pembagian kelompok berdasarkan tingkatan kelas diambil dari kelas 10 dan kelas 12 program akselerasi di SMA Negeri 8 yogyakarta. Sedangkan pembagian kelompok berdasarkan nilai akademik yang diperoleh dari nilai rapor siswa yang didapat dari guru kelas masing-masing.

Metode pengumpulan data digunakan melalui wawancara, observasi dan studi dokumen. Studi dokumen berupa nilai rapot masing-masing siswa untuk mengetahui kategori nilai mereka. Data yang diperoleh dari hasil wawancara, observasi dan studi dokumen dianalisis dengan menggunakan teknik trianggualasi data.

Jumlah keseluruhan populasi akseleran di SMA Negeri 8 Yogyakarta kurang lebih 39 orang. Partisipan dalam penelitian ini terbagi atas 2 lakilaki dan 4 perempuan masing masing berasal dari kelas X dan kelas XI. Untuk Kelas X jumlah akseleran 19 orang dan peneliti mengambil 3 orang perwakilan untuk dijadikan subjek penelitian dengan pertimbangan nilai akademik yang diperoleh dari masing-masing ketiga subjek tersebut yakni nilai akademik tinggi $=108.7$, nilai akademik sedang $=105.4$ dan nilai akademik rendah $=103.6$

Sama halnya dengan kelas XI dengan jumlah akseleran 20 orang dan peneliti mengambil 3 orang perwakilan untuk dijadikan subjek penelitian dengan pertimbangan nilai akademik yang di peroleh dari masing-masing ketiga subjek tersebut yakni nilai akademik tinggi $=91.35$, nilai akademik sedang 87.35 dan nilai akademik 84.35. Ada perbedaan penilaian dari kelas $\mathrm{X}$ dan kelas XI karena kelas $\mathrm{X}$ menggunakan penilaian kurikulum 2013 dan kelas XI masih menggunakan penilaian kurikulum 2006.

\section{Hasil dan Pembahasan}

\section{Gambaran School Well-Being Siswa Kelas Akselerasi dii SMA Negeri 8 Yogyakarta}

Hasil penelitian tentang gambaran school well being siswa kelas akselerasi di SMA Negeri 8 Yogyakarta, dideskripsikan kedalam 6 aspek yang meliputi Well Perceived On School Infrastructure, Excellent Individual Capital, unwell learning design management, well interpersonal school interaction. Well Perceived On School Infrastructure, kondisi ini menggambarkan 
bagaimana infrastruktur disekolah menentukan kenyamanan siswa. Penilaian subjektif siswa tentang sekolah dalam hal ini yaitu tentang pelayanan dan fasilitas sekolah yang diharapkan mampu menunjang proses pembelajaran di lingkungan sekolah sangatlah penting, karena dengan adanya dukungan fasilitas sekolah diharapkan siswa memiliki rasa puas dalam lingkungan belajarnya (Owoeye \& Yara, 2011). Penelitian yang dilakukan oleh Konu dan Lintonen (2005) mengungkapkan kondisi fisik sekolah yang paling perlu ditingkatkan aspek having yang mempengaruhi kepuasan siswa adalah ventilasi, fasilitas toilet, dan suhu, yang merupakan beberapa indikator dari aspek having yang mempengaruhi kepuasan siswa. Papalia, Olds, dan Feldman (2009) mengemukakan bahwa lingkungan sekolah (meliputi kualitas udara, temperatur, kelembaban, pencahayaan, dan tingkat kebisingan) yang sesuai dapat meningkatkan performa siswa. Dalam sekolah SMA 8 Yogykarta memiliki infrastruktur yang baik seperti kondisi lingkungan yang baik serta fasilitas seperti fasilitas perlengkapan belajar dikelas, fasiltas pembelajaran seperti laboratorium yang lengkap dengan fasilitas yang memadai, layanan perpustakaan, layanan kantin dan pelayanan konseling juga sanitasi toilet yang baik membuat keenam subjek merasa nyaman dengan keadaan lingkungan sekolah sehingga kegiatan belajar menjadi lebih kondusif. Ruang belajar yang dilengkapi pendingin ruangan juga membantu dalam pembelajaran yang nyaman. Kondisi sekolah yang kaya dengan penghijauan.

Excellent Individual Capital, kondisi ini menggambarkan kekuatan dasar yang ada dalam diri siswa yang memang prima. Dalam riset ini subjek penelitian ditemukan memiliki disiplin yang baik, motivasi yag tinggi, percaya diri dan fisik yang kuat serta kesehatan yang baik. Dalam kepribadian Big Five yaitu salah satu dimensinya adalah conscientiousness bahwa mereka seseorang yang bertanggung jawab, terorganisir, dapat diandalkan dan orang yang gigih (Feist, J \& Feist, G. J. 2008). Individu dengan tipe kepribadian ini digambarkan sebagai individu yang teratur, penuh pengendalian diri, terorganisasikan, ambisius, fokus pada pencapaian, dan disiplin diri, (Costa \& McCrae, 1999). Kedisiplinan yang dimiliki oleh subjek ada pengaruhnya dari peraturan yang dibuat oleh sekolah salah satunya adalah penerapan hukuman disekolah memberikan manfaat yang baik yakni menjadikan siswa menjadi insan yang disiplin terhadap peraturan yang dibuat. Hukuman adalah konsekuensi yang diberikan untuk menurunkan frekuensi munculnya suatu tingkah laku (Santrock, 2008). Tujuan diberikannya hukuman adalah untuk mengajarkan kedisiplinan bagi siswa. Oleh karena itu, pemberian hukuman harus dilakukan dengan tepat agar siswa mampu memahami tujuan dari hukuman tersebut (Santrock, 2008). Siswa akselerasi juga memiliki motivasi belajar yang tinggi terlihat dari bagaimana mereka menggunakan strategi belajar agar tetap memahami dan tidak ketinggalan pelajaran. Ormrod (2003) mengatakan bahwa siswa cerdas dan berbakat istimewa memiliki motivasi yang tinggi ketika menghadapi tugas-tugas yang menantang, mereka juga memiliki konsep diri akademik positif, memiliki fleksibilitas dalam berfikir, dan sangat fleksibel menggunakan pendekatan dalam belajar. Motivasi menurut Wlodkowsky (Sugihartono, 2007) merupakan suatu kondisi yang menyebabkan atau menimbulkan perilaku tertentu dan yang memberi arah dan ketahanan pada tingkah laku tersebut. Motivasi belajar yang tinggi tercermin dan ketekunan yang tidak mudah patah untuk mencapai kesuksesan meskipun dihadang oleh berbagai kesulitan, Sugihartono (2007). Siswa akselerasi juga memiliki tingkat percaya diri yang tinggi. Mereka percaya akan hasil kerja mereka sendiri terkait dengan pendidikan. Hal ini sejalan dengan teori Dave, Tripathi, Singh dan Udainiya (2011) menerangkan bahwa tingkat kesejahteraan dipengaruhi oleh efikasi diri, yang mana keyakinan mempengaruhi perilaku individu. Sehingga jika siswa merasa percaya diri terhadap kemampuannya, maka siswa akan lebih mampu melakukan kegiatannya di sekolah dan mendapatkan hasil akademis yang baik.

Status kesehatan merupakan salah satu aspek dalam kaitannya kesejahteraan individu yang memungkinkan dalam mengungkap kesehatan fisik, dan kesehatan mental remaja (Shaffer-Hudkins, Suldo, Loker, \& March, 2010). Oleh karena itu penting status kesehatan dalam school well-being untuk mengetahui adanya simptom-simptom yang dirasakan siswa di sekolah, agar tercapai kepuasan di sekolah yang menandakan kualitas sekolah yang baik. Siswa di kelas akselerasi di SMA 8 Yogyakarta memiliki kesehatan yang baik dan fisik yang kuat.

Unwell learning design management.proses mengelola yang meliputikegiatan perencanaan, pengorganisasian, pengendalian(pengarahan) dan pengevaluasian kegiatanyang berkaitan dengan proses membelajarkansi pebelajar dengan 
mengikutsertakan berbagai faktor di dalamnya guna mencapai tujuan, Made Wena (Pelana, 2012). Teori tersebut tidak sejalan dengan temuan dilapangan. Dalam penelitian ini menemukan bahwa siswa menilai kondisi sekolah yang tidak mampu memberikan kenyamanan pada mereka. Terlebih lagi pada pelayanan yang mungkin dianggap sepele namun krusial keberadaannya seperti waktu belajar yang padat dengan tugas yang banyak, istirahat yang kurang dan tidak tersedianya les atau bimbingan belajar disekolah. Hal ini merupakan design alokasi waktu yang turut berkaitan dengan belajar agar siswa tetap nyaman dalam lingkungan sekolah. Pemberian tugas kepada siswa harus dilakukan secara seimbang antara tugas sekolah dan tugas di rumah. Tugas yang diberikan secara berlebihan menimbulkan ketidakpuasan siswa di sekolah, Gilman \& Huebner (2003). Dalam peranannya sebagai pengelola kelas (learning manager), guru hendaknya mampu mengelola kelas sebagai lingkungan belajar serta merupakan aspek dari lingkungan sekolah yang perlu diorganisasi. Lingkungan ini diatur dan diawasi agar kegiatankegiatan belajar terarah kepada tujuan-tujuan pendidikan. Pengawasan terhadap belajar lingkungan itu turut menentukan sejauh mana lingkungan tersebut menjadi lingkungan belajar yang baik. Lingkungan yang baik ialah yang bersifat menantang dan merangsang siswa untuk belajar, memberikan rasa aman dan kepuasan dalam mencapai tujuan, Gilman \& Huebner (2003). Masalah yang ditemukan yang sangat memprihatinkan yaitu kondisi belajar mengajar yang cukup mengganggu dan tidak membuat nyaman bagi keenam subjek dalam penelitian ini dan mereka memawikili dari semua siswa akselerasi yang berada di SMA 8 tersebut. Mereka mengeluhkan metode mengajar guru yang mengajar disekolah mereka. Para subjek menemukan beberapa guru tidak menggunakan metode mengajar yang menurut mereka nyaman seperti guru yang monoton dalam mengajar yaitu membaca materi yang secara terus menerus dan mengajar yang sangat cepat dan juga mengajar sangat lambat. Hal ini membuat siswa akslerasi merasa bosan. Kondisi seperti ini berefek negatif terhadap semua siswa yakni mereka merasa lelah dan bosan. Hal ini juga sejalan dengan teori Kolesnik (1970) beban tugas belajar yang banyak bisa menjadi tekanan (stressor) bagi kesehatan mental.

Kegiatan belajar yang sangat padat, istirahat yang cukup mengakibatkan mereka lelah dan merasa bosan. Namun demikian para subjek penelitian ini memiliki strategi dalam belajar sehingga nilai yang diperoleh cukup membanggakan. Hal ini sejalan dengan teori Alsa (2006) yang menyatakan bahwa Aktivitas dan tugas belajar yang padat membuat siswa menggunakan banyak waktunya untuk belajar, melakukan kegiatan belajar bersama, menggunakan banyak sumber belajar, dan menggunakan berbagai strategi belajar, baik strategi kognitif maupun strategi mengelola lingkungan dan sumber daya. Aktivitas belajar yang padat menjadikan siswa kelas akselerasi mampu melakukan regulasi diri dalam belajar. Hasil penelitian yang dilakukan Ablard, dkk. (1994) menemukan bahwa sebagian besar siswa cerdas merasakan bahwa program akselerasi memberi dampak positif. Materi pelajaran yang menantang meningkatkan minat belajar siswa sehingga kemajuan belajarnya menjadi lebih cepat.

Well interpersonal school interaction. Dalam teori Loving (hubungan sosial) dalam aspek school well-being merujuk kepada lingkungan pembelajaran sosial, hubungan antara guru dan murid, hubungan dengan teman sekelas, dinamisasi kelompok, bullying, kerjasama antara sekolah dan rumah, pengambilan keputusan di sekolah, dan keselurahan atmosfir sekolah Konu \& Rimpelä (2002). Temuan dalam penelitian ini menyatakan bahwa siswa akselerasi memiliki interaksi yang positif baik itu kepada guru dan juga interaksi dengan teman sebaya. Mereka memiliki kerjasama yang bagus dalam tim. Dukungan sosial yang bersumber dari teman sebaya memiliki peran penting dalam meningkatkan school wellbeing siswa. Indivdu dengan dukungan teman sebaya yang tinggi akan mempunyai pikiran lebih positif terhadap sistuasi yang sulit dibandingkan indivdu untuk dukungan teman sebayanya rendah, Konu \& Rimpelä (2002). Namun, masalah yang ditemukan peneliti trekait dengan interaksi dengan teman sebaya, siswa akselerasi mengalami persoalan yakni kurang adanya interaksi dengan siswa reguler. Hal ini dikarenakan kegiatan belajar yang dilakukan secara terpisah. Salah satu kelemahan dari program akselerasi ini adalah dengan loncat kelas akan mengurangi kesempatan siswa untuk bersosialisasi dengan teman sebayanya, Kolesnik (1970). Ormrod (2003) mengatakan bahwa kemungkinan anak dengan kecerdasan istimewa mengalami kesulitan dalam pergaulannya dengan teman sebaya karena ia begitu berbeda dibandingkan dengan teman-teman sebayanya.

Well school management. Pelayanan sekolah meliputi layanan makan siang (kantin), pelayanan 
SCHOOL WELL-BEING, AKSELERASI

kesehatan, dan konseling (Konu \& Rimpelä, 2002). Sekolah memberikan pelayanan yang baik dan cepat seperti pelayanan dalam kesehatan ketika ada siswa yang sakit dan juga pelayanan konseling bagi siswa yang sedang menghadapi masalah serta pelayanan kantin. Salah satu aspek yaitu being dalam school well-being menurut Konu dan Rimpela (2002) merupakan kesempatan siswa yang diberikan sekolah untuk pemenuhan diri (selffulfillment). Pemenuhan diri yang dimaksud adalah usaha sekolah dalam memberikan apresiasi kepada siswa untuk turut mengambil peran dalam pengambilan keputusan, serta pengembangan diri melalui pengetahuan, dan ketrampilan sesuai bakat dan minat siswa, dimana sekolah sebagai lembaga payung yang bertugas mengawasi dan mengarahkan kegiatan siswa tersebut. Hal tersebut juga dapat berupa adanya kesempatan yang sama bagi semua siswa untuk menjadi bagian dari masyarakat sekolah, siswa dapat melakukan pengambilan keputusan terkait dengan keberadaannya di sekolah, serta adanya kesempatan untuk mengembangkan pengetahuan dan keterampilan berdasarkan minat siswa (Konu \& Rimpelä, 2002). Hal ini terlihat bagaimana sekolah memberikan kegiatan ekstrakurikuler dan kegiatan yang menuntun siswa untuk meningkatkan kreativitasnya.

Perceived parental support. Orang tua dalam keluarga berperan sebagai guru, penuntun, pengajar, serta sebagai pemimpin pekerjaan dan pemberi contoh (Novita, 2007). Oleh karena itu, sebagai orangtua harus dapat membantu dan mendukung terhadap segala usaha yang dilakukan oleh anaknya serta dapat memberikan pendidikan informal guna membantu pertumbuhan dan perkembangan anak tersebut serta untuk mengikuti dan melanjutkan pendidikan pada program pendidikan formal di sekolah. Orangtua memberi peranan penting dalam tahap belajar anak dan prestasinya, yaitu berupa dukungan dan support. Perhatian orangtua dapat memberikan dorongan dan motivasi sehingga anak dapat belajar dengan tekun, karena anak memerlukan waktu, tempat dan keadaan yang baik untuk belajar, Novita (2007). Mayoritas subjek peneltian mendapatkan dukungan penuh dari orangtua mereka, namun hanya satu subjek dari mereka mengalami sebaliknya yakni kurang mendapatkan dukungan dari orangtua.
Faktor-Faktor Yang Berkontribusi Terhadap School Well-Being Siswa Akselerasi Di SMA Negeri 8 Yogyakarta

Faktor-faktor yang berkontribusi terhadap school well-being siswa akselerasi di SMA Negeri 8 Yogyakartaterbagi menjadi dua yaitu faktor eksternal dan faktor internal. Faktor eksternal meliputi infrastruktur yang baik, managemen sekolah, interaksi yang baik antara guru maupun teman serta dukungan penuh dari orangtua. Sedangkan faktor internal adalah modal dasar personal siswa yaitu siswa yang memiliki motivasi belajar yang tinggi, disiplin yang tinggi, kerjasama yang baik, memiliki strategi belajar yang baik serta inisiatif belajar yang baik. Hal ini sejalan dengan teori bahwa beberapa faktor yang dapat mempengaruhi school well-being siswa menurut Keyes dan Waterman (Bornstein, Davidson, Keyes, \& Moore, 2003) yaitu hubungan sosial, teman dan waktu luang, volunteering, peran sosial, karakteristik kepribadian, kontrol diri dan sikap optimis, serta tujuan dan aspirasi. Pervin (Bornstein dkk, 2003) menyatakan bahwa individu yang memiliki rasa optimis mampu menyesuaikan diri dengan baik pada situasi tertentu seperti saat pergi ke sekoah. Selain itu individu yang optimis akan memiliki tingkat emotional well-being yang tinggi pula saat mengalami stres dibandingkan individu yang kurang optimis. Adapun penelitian dari Permata (2012) yang menunjukkan bahwa semakin tinggi keterlibatan siswa dalam kegiatan ekstrakurikuler, maka semakin tinggi school well-being yang dimiliki dan sebaliknya semakin rendah keterlibatan siswa dalam kegiatan ekstrakurikuler maka semakin rendah school well-being yang dimiliki.

\section{Simpulan}

Peneliti menyimpulkan bahwa Subjek SMA Negeri 8 Yogyakarta memiliki School Well-Being yang tinggi dan merasa nyaman berada disekolah mereka. Meskipun ada beberapa faktor negatif yang mempengaruhi ketidak nyamanan mereka disekolah. Namun, siswa mampu memecahkan masalah tersebut dengan baik. Faktor-faktor yang mempengaruhi mereka nyaman adalah dengan infrastruktur yang baik seperti suhu udara didalam kelas yang sejuk, sanitasi toilet yang baik, perpustakaan yang memadai serta nyaman, laboratorium yang nyaman, tempat ibadah yang nyaman, kantin yang nyaman dan bersih. Siswa 


\section{KHATIMAH}

akselerasi juga memiliki motivasi yang tinggi, disiplin yang tinggi, percaya diri yang tinggi serta kondisi fisik yang kuat sehingga mereka mampu beradaptasi dengan kondisi sekolah. Manajemen sekolah juga dirasakan nyaman oleh mereka seperti pelayanan kesehatan, pelayanan konseling dan juga pelayanan administrasi sekolah.

Sekolah juga menyediakan kegiatan ekstrakurikuler yang bervariatif sehingga siswa dengan bebas mengikuti. Sekolah memberikan kegiatan-kegiatan positif yang menunjang performa siswa serta kreativitas. Sekolah juga selalu melibatkan siswa dalam pengambilan keputusan disekolah seperti pemilihan osis atau kegiatankegiatan lainnya. Sekolah membentuk hubungan interpersonal yang baik seperti interaksi antara siswa dan guru yang baik, interaksi dengan teman sebaya yang baik, serta hubungan sekolah dengan orangtua siswa dengan mengadakan pertemuan secara rutin. Kerja sama yang baik juga terjalin antar siswa dan guru-guru disekolah.

Peneliti menemukan siswa yang tidak merasa nyaman ketika berada di sekolah yakni terkait dengan manajemen pembelajaran sekolah seperti buku ajar yang kurang, koneksi internet yang masih sukar untuk dijangkau, waktu belajar yang sangat padat serta waktu istirahat yang dirasakan tidak cukup. Metode mengajar guru juga menjadi hal yang penting untuk dibahas, siswa mengeluhkan metode guru yang beberapa tidak sesuai dengan belajar siswa. Terjadinya diskriminasi terhadap siswa yang memiliki prestasi rendah, sekolah juga tidak menyediakan bimbingan belajar diluar sekolah. Sekolah tidak memberikan bekal tentang orientasi masa depan kepada siswa. Ada juga masalah negatif yang dihadapi adalah beberapa orangtua dari salah satu subjek tidak memberikan dukungan dan support kepada anaknya dan tidak memberikan memberikan kebebasan untuk memilih apa yang diinginkan untuk masa depannya. Adapun temuan yang cukup unik adalah ada siswa yang tidak percaya dengan hasil kerja teman-temannya sehingga siswa tersebut selalu mengerjakan tugas kelompok yang diberikan. Subjek juga mengalami negative diversionn to motivate himself yakni subjek dengan secara sengaja untuk tidak menyukai pelajaran yang sebenarnya dirasakan mudah untuk dikerjakan, hal ini dilakukan untuk meningkatkan motivasi belajar dan tidak menyepelekan pelajaranpelajaran tersebut.

Peneliti menemukan faktor-faktor yang berkontribusi terhadap school well-being pada siswa akselerasi di SMA Negeri 8 Yogyakarta yaitu faktor eksternal yang meliputi infrastruktur yang baik, managemen sekolah, interaksi dengan guru maupun teman sekolah baik dan dukungan orangtua baik. Sedangkan faktor internal adalah modal dasar personal siswa yang sudah dimiliki seperti motivasi yang tinggi, disiplin yang tinggi, kerjasama yang baik, memiliki inisiatif belajar yang tinggi serta mampu menciptakan strategi belajar yang baik. Hasil penelitian ini dapat dijadikan dasar pertimbangan sekolah dalam menciptakan iklim belajar yang mengarah pada kondisi sekolah yang well being

\section{Referensi}

Alsa, A. (2004). Keunggulan dan Kelemahan Program Akselerasi di SMA: Tinjauan Psikologi Pendidikan. anima. indonesian psychology Jurnal. Vol. 22 (4) 309-318.

Bornstein, M.H., Davidson, L., Keyes, C.L.M., \& Moore, K.A. (2003). Dimensions ofWell-Being and Mental Health in Adulthood. Well-Being: Positive DevelopmentAcross the Life Course. Mahwah, NJ: Lawrence Erlbaum Associates, Inc.

Dalyono, M. (2012). Psikologi pendidikan. Jakarta: PT. Rineka Cipta.

Dave, R., Tripathi, K. N., Singh, P., \& Udainiya, R. (2011). Subjective wellbeing, locus of control and general self-efficacy among university students. Amity Journal of Applied Psychology, Vol. 2 (5), 28-32.

Davis, G.A. (2012). Anak Berbakat Dan Pendidikan Keberbakatan : Suatu Buku Panduan Untuk Guru Dan Orangtua. Jakarta: PT Indeks.

Fatimah, B.S. (2010). Hubungan antara stress dengan school well-being pada siswa kelas XI SMA Negeri di Jakarta. Skripsi (Tidak diterbitkan). Depok: Fakultas Psikologi Universitas Indonesia.

Faubert, V. (2009). School Evaluation: Currrent practices in OECD countries and literature review. Paris:Dalam OECD Education Working Papers, No. 42.

Feist, J., \& Feist, G. J. (2008). Theories of Personality. Yogyakarta: Pustaka Pelajar.

Fraillon, J. (2004). Measuring student well-being in context of Australian Schooling. The Australian Council for Educational Research. Discussion Paper.

Gilman, R., \& Huebner, S. (2003). A Review of Life Satisfaction research with Children and 
Adolescents. School Psychology Quarterly, Vol. 18 (2), 192- 205.

Hawadi, A.R. (2004). Akselarasi: A-Z Informasi Program Percepatan Belajar Dan Anak Berbakat Intelektual. Jakarta: Grasindo.

Huebner, S.E., \& McCullough, G. (2000). Correlates of school satisfaction among adolescents. The Journal of Educational Research. Vol 93 (5). 331-335.

Karyani, U. (2013). Keluarga Sebagai Ranah Utama Kesejahteraan Siswa. Prosiding Seminar Nasional Parenting 2013.

Kolesnik, W.B. (1970). Educational Psychology. New York: McGraw-Hill Book Company.

Konu, A. I., \& Rimpela, M. (2002). Well-being in schools: A conceptual model. Journal ofHealth Promotion International Vol. 17, No. 1 , 79-87.

Konu, A. I., Lintonen, T. P., (2006). School wellbeing in Grades 4-12. Journal of Health Education Research Vol. 21 (5), 633-642.

Moleong, L.J. (2010). Metode Penelitian Kualitatif. Bandung: PT. Remaja Rosda Karya.

Morris, Ian. 2009. Teaching Happiness And WellBeing in Schools. New York: Mixed Souces.

Muhid, Abdul., \& Rohmatillah, Nely. (2010). Perbedaan Penyesuaian Sosial Antara Siswa Program Akselerasi Dengan Siswa Program Reguler Di SMA Negeri 5 Surabaya. Jurnal Proyeksi, Vol 4 (2), 1-12.

Munandar, U. (1999). Pengembangan Kreativitas Anak Berbakat. Jakarta: Rineka Cipta.

Novita, W. (2007). Serba Serbi Anak, Yang Perlu Diketahui Seputar Anak Dari Dalam Kandungan Hingga Masa Sekolah (Tinjauan Psikologi Dan Kedokteran). Jakarta : PT. Elex Media Komputindo.

Omrod, J.E. (2003). Educational Psychology, Developing Learners. New Jersey: Upper Saddle River.

Owoeye, J.S \& Yara, P.O. (2011). School Facilities And Academic Achievement of Secondary SchoolAgricultural Science in Ekiti State, Nigeria. Journal of Asian Social Science Vol.7.64-74.

Papalia, D.E., Olds, S.W., \& Feldman, R.D. (2009). Human Development. New York: McGraw-Hill.

Pelana, R. 2012. Manajemen Pembelajaran YangMenyenangkan Pada Mata PelajaranPendidikan Jasmani Olahraga DanKesehatan (Pjok). Jurnal Pendidikan Dasar Vol. 3 (5), 185-192.

Poerwandari, E.K. (1998). Pendekatan Kualitatif Dalam Penelitian Psikologi. Jakarta: Lembaga
Pengembangan Sarana Pengukuran dan Pendidikan Psikologi. Fakultas Psikologi UI.

Rogers, K. B. (2002). Acceleration. JournalEducational Acceleration. Spring 2002, Vol. 24 (3), 47-57.

Santrock, J. W. (2008). Psikologi Pendidikan. Jakarta: Kencana Predana Media Group.

Satori, D \& Komariah. A.( 2010). Metode Penelitian Kualitatif. Bandung: Alfabeta.

Shaffer, H. E., Suldo, S., Loker, T., \& March, A. 2010. How Adolescents' Mental Health Predicts Their Physical Health: Unique Contributions Of Indicators Of Subjective W ell-Being And Psychopathology. JournalAppliedResearch in Quality of Life. Volume 5 (3), 203-217.

Sugihartono, Fathiyah, K. N., Harahap, F., Setiawati, F. A., \& Nurhayati, S. R. (2007). Psikologi Pendidikan. Yogyakarta: UNY Press

Sugono, (2005). Kamus Besar Bahasa Indonesia. Departemen Pendidikan Nasional: Balai Pustaka. 